\title{
THIRD GENERATION LEARNING IN BUSINESS ENGLISH
}

\author{
Jelena Stepanova \\ University of Latvia, Latvian Business College, Latvia
}

\begin{abstract}
Third generation learning in Business English is a tool increasing students' lifelong competences and achievements. Business English today is about communication where the content and the communicative competences- linguistic, sociolinguistic and pragmatic are of crucial importance. The article reflects the results of $3^{\text {rd }}$ generation learning in Business English in post-secondary institution in Latvia where students using team-based learning in the classroom mastered their language skills and communicative competences to achieve an academic success.
\end{abstract}

Keywords: third generation learning, team-based learning, Business English.

\section{Introduction}

Nowadays our society requires young people to be not only intelligent and educated, but as well proactive, adaptable and creative. Modern generation has to be able to communicate efficiently, solve non-standard problems, develop critical thinking and work effectively within teams. It is not sufficient to have 'knowing of knowledge' in the $21^{\text {st }}$ century.

Besides, the $21^{\text {st }}$ century is an era of new information and communication technologies. Earlier the focus was on a technology-centered way of education, but nowadays the process of changing from technology-centered concept to more human-centered concept is going on, where IT technologies are used for various business, learning and communication means.

Alongside with technologies the modern society shows adherence to business education which becomes more and more popular today. A significant place in the business college syllabus takes Business English as a main language of communication in the international business environment and one of the two foreign languages which modern European citizens are expected to know according to Common European Framework of Reference (2001).

Thus, everything changes and nothing stands still, including teaching. Flipped classrooms or e-learning are our reality today, however, it is important to remember that the priority should be given to human-centered approach, e.g. communication and teachers should learn to combine all possible means and techniques like third generation learning to engage students and motivate them to learn. 
The aim of the given paper is to analyze the theory-grounded investigation to trace if the third generation learning is good for Business English teaching and therefore serves as approbation of this stage of this research to continue it, as well as what the priorities are and if the learners accept them.

The present paper is an example of an interdisciplinary research and lies at the border of such areas as linguistics, educational sciences, sociology and psychology. Mixed methods were used as the approach to research design.

\section{Business English teaching-learning}

The modern English language teaching in Europe counts more than 250 years. The history of Business English teaching counts around 50 years. The changes in emphasizing the importance of distinguishing Business English into a separate area and teaching differently were caused by four main tendencies: changes in the world, changes in linguistics, changes in educational psychology and changes in knowledge management where learners are knowledge managers and knowledge producers (Hutchinson, 1987), (Widdowson, 1978), (Rodgers, 1969). Thus, in its development Business English teaching focused on three main features: students' needs, language approach and learning approach.

In its development, Business English teaching progressed through six stages, from register analysis (1960-ies) and discourse analysis (1970-ies) to learner-centered approach and communication approach in the 1980-ies and evolved to business communication in typical business situation. (Hutchinson, 1987)

Frendo (2005) wrote that business people "need English to do business, not just to talk about business". It means the students or future successful businessmen should obtain not only great linguistic skills, but as well critical thinking skills which are important in decision-making and ability to respect and trust the partners, both in the classroom or in the conference room.

Business English today is about communication where the content is of crucial importance, besides the communicative competences- linguistic, sociolinguistic and pragmatic, play its role. It means if the teacher intends to develop these competences apart from developing main skills and competences of Business English, the focus should be not only on the development of language skills but also on how to use language in social and cultural context and in interpersonal relationships, especially nowadays when the classes are often multinational and multicultural. To achieve all these objectives the third generation learning might be applied. 


\section{Third generation learning}

"To teach is to engage students in learning" (Christensen et al., 1991). In third generation learning the learners choose their own self determined routes through the content. Each learner will become a nexus of knowledge, and a node of content production. The third generation learning is a facet of an ongoing, limitless symbiotic relationship between human and machine. (Steve Wheeler, 2012)

Communication and cooperation are of great importance for Business English, because it teaches students to control their thoughts and words they say in English, they pay more attention to language structure and Business English style. Talking is recognized such a significant part of learning that it is considered more important than means of sharing thoughts, as individual talking is a key to learning. The passive listening to the knowledgeable peers who are sharing answers does not replace the active talking itself.

In spite of acknowledgement of all benefits from interacting student with each other, the role of teachers in the process of learning should not be denied. The teacher arranges the directed content lessons, reading, cases on concepts and principles via flipped classroom methods where the responsibility of initially learned content is placed outside the classroom and further promotes the students' talking in the classrooms and independence in learning. It is obvious that teachers are the key players who introduce students into ways of thinking and learning by explaining how to express ideas, ask for a help, defend own positions in the dialogues and reason properly - all what the third generation learning model practices and what leads the learners towards their personal achievements in acquiring Business English. Thus, this is undoubtedly that teachers facilitate to acquire the linguistic tools necessary to develop critical and creative thinking, to learn cooperatively and creatively through the third generation learning for higher achievements, to acquire the autonomy in reasoning and making the right decisions.

If we are talking about third generation learning it makes sense to distinguish the stages of generation evolution, to analyze its peculiarities and to compare it with social generations from the beginning of 20th century untill nowadays. It will help see the differences and to avoid repeating of the old approaches which might traditionally appear in teaching-learning. Also, it will demonstrate the direction of the teaching-learning process transformation from teaching general English in silent way as in first generation learning to interactive teaching Business English in teams as in third generation learning. The crucial point in such development was the reflection of social changes in the world on the characteristics of students, who belong to different generation: Traditional, Baby boomers, Gen X, Y, Z (Lancaster et al, 2002). The self- 
perception, common beliefs and behaviours, historical trends and significant events (Howe et al, 2000), influenced on the English teaching/learning styles and approaches and led to the changes and transformations reflected in Table 1.

Table 1 Educational and social generational features

\begin{tabular}{|c|c|c|c|c|c|}
\hline \multirow[t]{2}{*}{ Features } & \multicolumn{5}{|l|}{ Generations } \\
\hline & Traditional & \begin{tabular}{|l} 
Baby \\
boomers
\end{tabular} & Gen $X$ & Gen $Y$ & Gen Z \\
\hline Born & $1900-1945$ & 1946-1964 & $1965-1980$ & $1981-2000$ & 2000-present \\
\hline $\begin{array}{l}\text { Age (as at } \\
\text { 2016) }\end{array}$ & $\begin{array}{l}71 \text { and } \\
\text { above }\end{array}$ & $55-70$ & $36-56$ & $15-35$ & $16-0$ \\
\hline Values & $\begin{array}{l}\text { Discipline, } \\
\text { stability, } \\
\text { logic }\end{array}$ & $\begin{array}{l}\text { Questions } \\
\text { authority, } \\
\text { recognition, } \\
\text { idealistic, } \\
\text { optimistic } \\
\end{array}$ & $\begin{array}{l}\text { Flexibility, } \\
\text { portability, } \\
\text { skepticism }\end{array}$ & $\begin{array}{l}\text { Change, diversity, } \\
\text { motivated, } \\
\text { freedom, realistic }\end{array}$ & $\begin{array}{l}\text { Technology, } \\
\text { multi-profiled }\end{array}$ \\
\hline $\begin{array}{l}\text { Teaching } \\
\text { styles }\end{array}$ & $\begin{array}{l}1^{\text {st }} \\
\text { generation- } \\
\text { Teacher } \\
\text { centered } \\
\end{array}$ & $2^{\text {nd }}$ generation & $\begin{array}{l}\text { Transfer from } \\
2^{\text {nd }} \text { to } 3^{\text {rd }} \\
\text { generation- } \\
\text { Student-centered }\end{array}$ & $3^{\text {rd }}$ generation & $\begin{array}{l}3^{\text {rd }}, 4^{\text {th }} \text { and } 5^{\text {th }} \\
\text { generation }\end{array}$ \\
\hline $\begin{array}{l}\text { Learning } \\
\text { styles }\end{array}$ & $\begin{array}{l}\text { Silent } \\
\text { learning }\end{array}$ & $\begin{array}{l}\text { Conscious } \\
\text { control } \\
\text { learning }\end{array}$ & $\begin{array}{l}\text { Cooperative } \\
\text { learning, } \\
\text { problem-based } \\
\text { learning, self- } \\
\text { directed learning }\end{array}$ & $\begin{array}{l}\text { Transformational } \\
\text { learning, Team- } \\
\text { based learning }\end{array}$ & $\begin{array}{l}\text { Eclectic } \\
\text { learning. } \\
\text { Mixed } \\
\text { learning. Case } \\
\text { study learning. } \\
\text { Partnership } \\
\text { learning, } \\
\text { Team-based } \\
\text { learning, } \\
\text { Blended } \\
\text { learning, E- } \\
\text { learning }\end{array}$ \\
\hline $\begin{array}{l}\text { General } \\
\text { English } \\
\text { teaching } \\
\text { approach }\end{array}$ & $\begin{array}{l}\text { English- } \\
\text { Grammar } \\
\text { Translation } \\
\text { method, } \\
\text { Direct } \\
\text { method, } \\
\text { Silent } \\
\text { reading }\end{array}$ & $\begin{array}{l}\text { Audio-lingual } \\
\text { method, } \\
\text { Structuralism, } \\
\text { Cognitive } \\
\text { code } \\
\text { approach }\end{array}$ & $\begin{array}{l}\text { Natural } \\
\text { approach. } \\
\text { Suggestopedia, } \\
\text { Humanistic } \\
\text { Approach, } \\
\text { Neuro-linguistic } \\
\text { programming. } \\
\text { Community } \\
\text { language } \\
\text { learning }\end{array}$ & $\begin{array}{l}\text { The silent way. } \\
\text { Communicative } \\
\text { approach. Total } \\
\text { physical } \\
\text { response. Lexical } \\
\text { approach. } \\
\text { Content-based } \\
\text { method. Task- } \\
\text { based instructions }\end{array}$ & $\begin{array}{l}\text { Principled } \\
\text { eclecticism }\end{array}$ \\
\hline
\end{tabular}




\begin{tabular}{|c|c|c|c|c|c|}
\hline $\begin{array}{l}\text { Business } \\
\text { English } \\
\text { teaching } \\
\text { approach }\end{array}$ & - & $\begin{array}{l}1^{\text {st }} \text { generation } \\
1960 \text {-ies } \\
\text { Register } \\
\text { analysis }\end{array}$ & $\begin{array}{l}2^{\text {nd }} \text { generation } \\
1970 \text {-ies } \\
\text { Discourse } \\
\text { analysis }\end{array}$ & $\begin{array}{l}3^{\text {rd }} \text { generation } \\
1980-i e s \text { Target } \\
\text { situation analysis } \\
4^{\text {th }} \text { generation } \\
1980 \text {-ies Skills- } \\
\text { centered approach } \\
5^{\text {th }} \text { generation } \\
1990 \text {-ies Learner- } \\
\text { centered approach } \\
6^{\text {th }} \text { generation } \\
\text { Communicative } \\
\text { approach }\end{array}$ & $\begin{array}{l}\text { Principled } \\
\text { eclecticism }\end{array}$ \\
\hline $\begin{array}{l}\text { Communica } \\
\text { tion }\end{array}$ & Low & $\begin{array}{l}\text { Low/ } \\
\text { Middle }\end{array}$ & $\begin{array}{l}\text { Middle/ } \\
\text { High }\end{array}$ & High/Very high & Very high \\
\hline
\end{tabular}

It is obvious how the social developments in the society transformed the teaching-learning approaches from teacher-centered ( $1^{\text {st }}$ generation learning) through conscious control learning ( $2^{\text {nd }}$ generation learning) and team-based learning ( $3^{\text {rd }}$ generation learning) further to blended learning $\left(4^{\text {th }}\right.$ generation learning) and e-learning ( $5^{\text {th }}$ generation learning). Looking at historical overview of the essentialities in each stage it is possible to highlight the tendencies for each stage implementation and as well predict that in future the new stages, i.e. generations in teaching and learning will appear and be adopted in the Business English classrooms.

\section{Team-based learning as third generation learning tool in business English}

The paper is focused on illustrating how the third generation learning in Business English can advance academic success, i.e. an ability to speak, read, write, and comprehend Business English through critical thinking, team work, trust, and mutual respect. The approbation of the third generation learning was carried out using team-based learning (TBL) approach; as TBL is one of the tools expressing the essence of third generation learning; besides there was no evidence that TBL was used in Business English classroom earlier that is why it seemed valuable to research it.

TBL incorporates various theories of adult learning such as cooperative theory (May and Doob, 1937), theory of margin (McClusky, 1970), three dimensions of learning model (Illeris, 2002, 2004), lifelong and self-directed learning (Tough, 1967, 1971), transformational learning (Mezirov, 1991), model of learning process (Jarvis, 2006), and pedagogies of engagement (Engerton, 2001). 
Thus, in the research in Business English class participated 15 first-year students from the Faculty of Management, Latvian Business College, from October 2015 until January 2016. Their age is from 19 to 25, the English Language Proficiency Level according to the results of placement tests is B1 (intermediate level).

Team-based learning (TBL) concept includes grouping students into diverse teams of 5-7 students that work together throughout the class. (Michaelsen et al. 2004)

In team-based learning the pre-class preparation is important where the teacher has to organize the learning materials to enable students to take responsibility on their own and their peers' learning process with following inclass team discussion and application of their knowledge in classroom. If students take individual accountability, it will provoke the better team interaction. This accomplishes all three competences-what individuals know or are able to do in terms of knowledge, skills and attitude and productivity - extent to which individuals can adapt to generate new knowledge and continue to improve performance communicating with others. In the class at the beginning of new theme, the students complete the individual Readiness Assurance Test (iRAT) and then complete the same test with their group members -the group Readiness Assurance Test or (gRAT). Both the individual scores and the group scores contribute to the students' mark. The tests are typically multiple choice; however, open questions also might take place.

After the students complete the group test, the teacher discusses the answers and encourages students to appeal questions that they got incorrect. The discuss session encourages students to review the material, evaluate their understanding, and defend the choice they made. To conclude the Readiness Assurance Process, the teacher gives a lecture that focuses on concepts with which students struggled the most (Sweet, 2012). Afterwards, the additional practice exercises are introduced.

The questionnaires and observations were used as a research method to evaluate the success of TBL in Business English classes. The TBL outcomes (student's interest, confidence, linguistic skills) in Business English classes at Latvian Business College are summarized in the Table 2.

The analysis of TBL outcomes in Business English classes demonstrates that $87 \%$ of students find the lectures where TBL method was used clear and understandable, $93 \%$ agree that the lectures increased their understanding of the subject, $100 \%$ suppose that it was interesting to learn via this method, and $94 \%$ believe that the lectures improved their general analytical and critical skills as well as skills to learn in teams. Analyzing the comments to the question 'What did you like most about this theme' $45 \%$ of students wrote 'work in teams' (other answers were more specific about the material of the lesson), what 
emphasizes the interest and engagement in team work on the lesson. In the comments answering the question 'What did you like least?' $15 \%$ of students wrote about reading long texts, what tells that long pre-class individual preparations did not bother the majority of class.

Table 2 Analysis of TBL outcomes in Business English

\begin{tabular}{|l|l|l|l|l|}
\hline \multirow{2}{*}{ TBL outcomes } & \multicolumn{4}{|c|}{ Evaluation } \\
\cline { 2 - 5 } & $\begin{array}{l}\text { Strongly } \\
\text { agree }\end{array}$ & Agree & $\begin{array}{l}\text { Not } \\
\text { strong } \\
\text { feelings }\end{array}$ & $\begin{array}{l}\text { Disagree/ } \\
\text { Strongly } \\
\text { disagree }\end{array}$ \\
\hline 1. The lessons were clear and understandable & $54 \%$ & $33 \%$ & $13 \%$ & - \\
\hline $\begin{array}{l}\text { 2. The lessons increased my understanding of } \\
\text { the subject }\end{array}$ & $33 \%$ & $60 \%$ & $7 \%$ & - \\
\hline 3. The lessons were interesting & $47 \%$ & $53 \%$ & - & - \\
\hline $\begin{array}{l}\text { 4. Contribution of these lessons in improving } \\
\text { your general analytical and critical skills }\end{array}$ & $27 \%$ & $67 \%$ & $6 \%$ & - \\
\hline $\begin{array}{l}\text { 5. Contribution of these lessons in improving } \\
\text { your skills to learn in teams }\end{array}$ & $47 \%$ & $47 \%$ & $6 \%$ & - \\
\hline
\end{tabular}

\section{Conclusion}

Summarising the research analysis it can be concluded, that team-based learning, as a tool of third generation learning in teaching Business English, seems successful: it assisted to academic achievements both in linguistic and communication through critical thinking, team work, trust and mutual respect and incorporated peer-group teaching with enthusiasm for learning of Business English.

In the well-organized by teacher learning process where students are motivated to communicate and learn in teams discussing the new material, the success and achievements are higher and students are better prepared for independent life-long learning because of constant practice. The theorygrounded investigation was analyzed and its results prove that there is a link between third generation learning in Business English and progress in language and business communication style as:

- $\quad$ students communicated more on the lesson among themselves instead of passive listening to the teacher;

- they learned to think critically and then express their language knowledge in speaking and writing;

- they prepared independently to the lessons, reading the provided materials and analysing it, and then collaborated in teams trying to find the correct answer; 
- $\quad$ they learned to respect each other and solve all problems by talking with each other.

Around $90 \%$ of students positively evaluated the introduction of this approach and acknowledged that they developed such skills as critical thinking and ability to work in teams. However, the teacher to contribute to TBL success should make sure that:

- the course content is complex enough to justify team formation for TBL, otherwise the students will be bored and demotivated;

- the teacher should be flexible and creative with the materials to adjust the syllabus to follow the TBL concept and not to miss the linguistics aspects of the discipline;

- the criteria of assessment and mutual evaluation should be transparent to make the value of cooperation obvious.

\section{References}

Hutchinson, T. (1987). English for Specific Purposes. UK: Cambridge University Press.

Widdowson, H. (1978). Teaching Language as Communication. UK: Oxford University Press.

Rodgers, C. (1969). Freedom to Learn, USA: Merrill.

Jones, G., \& Sallis, E. (2002). Knowledge Management in Education. UK: Routledge.

Frendo, E. (2005). How to Teach Business English. UK: Pearson Education Limited.

Bentley, K. (2010). The TKT Course CLIL Module. UK: Cambridge University Press.

Chambers, F. (1980). A Re-evaluation of Needs Analysis. UK: ESP Journal.

Munby, J. (1978). Communicative Syllabus Design. UK: Cambridge University Press.

Christensen, C. R., Garvin, D. A., \& Sweet, A. (1991). Education for Judgment: The Artistry of Discussion Leadership, USA: Harvard Business School.

Vygotsky, L. (1997). Educational Psychology. USA: St. Lucie Press.

May, M., \& Doob, L. (1937). Competition and Cooperation. USA: Social science research council.

McClusky, Y. (1970). An Approach to a Differential Psychology of the Adult Potential. USA: ERIC Clearinghouse on Adult Education.

Illeris, K. (2009). Contemporary Theories of Learning. UK: Routledge.

Tough, A. (1967). Learning without a Teacher: A Study of Tasks and Assistance during Adult Self-Teaching. Canada: Ontario Institute for Studies in Education.

Mezirow, J. (1991). Transformative Dimensions of Adult Learning. USA: Jossey-Bass Higher and Adult Education.

Jarvis, P. (1987). Adult Learning in the Social Context. USA: Croom Helm.

Edgerton, R. (2001). Education White Paper.

Lancaster, L., \& Stillman, D. (2002). When Generations Collide. Who They Are. Why They Clash. How to Solve the Generational Puzzle at Work. USA: Collins Business.

Howe, N., \& Strauss, W. (2000). Millennials Rising: The Next Great Generation. USA: Vintage Books.

Michaelsen, L., Bauman-Knight, A., \& Fink, D. (2004). Team-based Learning: A Transformative Use of Small Groups in College Teaching. USA: Stylus Publishing. 
SOCIETY. INTEGRATION. EDUCATION Proceedings of the International Scientific Conference. Volume I, May $27^{\text {th }}-28^{\text {th }}$, 2016. 241-249

Sweet, M., \& Michaelsen, L. (2012) Team-Based Learning in the Social Sciences and Humanities: Group Work that Works to Generate Critical Thinking and Engagement. USA: Stylus, Sterling.

Wheeler, S. (2012). http://steve-wheeler.blogspot.co.uk/2012/11/next-generationlearning.html. 